\title{
HUBUNGAN KESIAPAN BELAJAR, LAMA PEMBELAJARAN, KESESUAIAN TEMPAT DAN PARTISIPASI DU/DI DENGAN HASIL PRAKERIN PESERTA DIDIK KOMPETENSI KEAHLIAN TKJ DI SMK KOTA BATU
}

\author{
Ahmad Mursyidun Nidhom, Ahmad Sonhadji K.H, Dwi Agus Sudjimat \\ Program Studi Pendidikan Kejuruan \\ Pascasarjana Universitas Negeri Malang \\ nidhom.informatika@gmail.com
}

\begin{abstract}
Abstrak. Penelitian ini bertujuan untuk mengetahui hubungan serta sumbangan efektif kesiapan belajar, lama pembelajaran, kesesuain tempat dengan hasil prakerin peserta didik kompetensi keahlian TKJ di SMK Kota Batu. Rancangan penelitian menggunakan pendekatan kuantitatif dengan jenis penelitian korelasional. Sampel yang digunakan sebanyak 48 peserta didik yang diambil dengan teknik simple random sampling. Instrumen yang digunakan adalah dokumentasi nilai hasil prakerin dan angket. Uji hipotesis menggunakan uji korelasi ganda dan regresi ganda. Hasil uji hipotesis keempat variabel menghasilkan nilai Sig $(p)=0,000$ (kesiapan belajar), 0,013 (lama pembelajaran) dan 0,000 (kesesuain tempat) dan 0,000 (partisipasi DU/DI) sehingga $\mathrm{H}_{0}$ diterima. Jadi, artinya terdapat hubungan yang signifikan antara variabel kesiapan prakerin, variabel lama proses prakerin, variabel kesesuain tempat prakerin dan variabel partisipasi DU/DI dengan hasil prakerin peserta didik kompetensi keahlian TKJ di SMK Kota Batu pada taraf signifikansi 5\%. Hasil uji regresi ganda diperoleh nilai $\operatorname{Sig}(\mathrm{p})=0,000<0,05$, sehingga $\mathrm{H}_{0}$ diterima. Jadi, artinya terdapat hubungan yang signifikan antara kesiapan prakerin, lama proses prakerin, kesesuain tempat prakerin dan partisipasi DU/DI secara bersama-sama dengan hasil prakerin peserta didik kompetensi keahlian TKJ di SMK Kota Batu pada taraf signifikansi 5\%. Sumbangan efektif keempat variabel adalah $58 \%$, sedangkan $42 \%$ sisanya dari faktor lain yang tidak diteliti.
\end{abstract}

Kata kunci: kesesuaian tempat, kesiapan belajar, lama pembelajaran, partisipasi DU/DI, prakerin.

\begin{abstract}
The aim of this research is to know the relationship and donations effectivity for the readiness of learning, the long of learning, the suitable of place, the participation of workstation with the results of apprenticeship competency skills of TKJ students at SMK Batu City. The planning of this research using quantitative approach with the kind of research correlations. Samples used a total of 48 students taken with simple random sampling techniques. An instrument used is the result of document apprenticeship value and quesioner. The hypotheses test use multiple correlation and multiple regression. The results of thirth test hypotheses is the value of a variable produce Sig $(p)=0,000$ (the readiness of learning), 0,013 (the long of learning), 0,000 (the suitable of place) and 0,000 (participation of workstation) $<0,05$, so $\mathrm{H}_{0}$ accepted. So, it means that there is a significant relation of variable the readiness of learning, variable the long of learning, variable the suitable of place and variable participation of workstation with the result apprenticeship competency skills of TKJ students in SMK Batu City. In standard significance $5 \%$. The results of the multiple regression test obtained value sig $(\mathrm{p})=0,000<0.05$, so $\mathrm{H}_{0}$ accepted. So, it means there is a significant relation between readiness of learning, the long of learning, the suitable of place and the participation of workstation jointly with the results of apprenticeship students competency skills of TKJ students in SMK Batu City. In standard significance 5\%. The contribution of effective fourth variable is $58 \%$, while $42 \%$ and the rest from various other factors.
\end{abstract}

Keywords: apprenticeship, the readiness of learning, the long of learning, the suitable of place, the participation of workstation, the result of apprenticeship 


\section{PENDAHULUAN}

Pendidikan merupakan aspek penting yang menjadi kebutuhan utama setiap manusia. Dengan pendidikan dapat tercipta perubahan sikap yang baik pada diri seseorang. Hal ini memberikan makna bahwa dengan pendidikan akan terwujud manusia yang berbudi luhur dan bermartabat, sesuai dengan amanat UUD 1945 dan UU Sisdiknas yang telah dipaparkan. Karenanya masalah pendidikan merupakan masalah yang menyangkut kepentingan semua orang, bukan hanya menyangkut investasi dan kondisi bangsa di masa yang akan datang, tetapi juga dampaknya akan dirasakan saat ini (Kuncoro, 2009). Itulah sebabnya pendidikan senantiasa memerlukan upaya perbaikan.Sebagai bagian dari pendidikan nasional, Sekolah Menengah Kejuruan (SMK) juga memegang peranan penting dalam memajukan bangsa, yakni untuk menyiapkan sumber daya manusia yang siap memasuki dunia kerja dan menjadi tenaga kerja yang produktif. Lulusan SMK idealnya merupakan tenaga kerja yang siap pakai, dalam arti langsung bisa bekerja di dunia usaha dan industri (DU/DI). Permasalahan SMK saat ini pada umumnya terkait dengan keterbatasan peralatan, masih rendahnya biaya praktik, dan lingkungan belajar yang tidak serupa dengan dunia kerja. Kondisi tersebut bisa menyebabkan ketidaksiapan lulusan dalam memasuki dunia kerja, sehingga dapat menimbulkan efek domino bagi industri pemakai.

Di negara-negara maju, peran industri ditunjukkan secara nyata berupa kerja sama program, dukungan finansial untuk penelitian dan beasiswa. Bahkan di beberapa negara peran industri ini sudah menjadi kewajiban karena telah ada undang-undang yang mengaturnya. Paling tidak dunia usaha dan industri yang telah secara nyata membangun kerjasama dengan sekolah diberi insentif dengan memberikan keringanan pajak (Camp and Hilison, 1984).

Salah satu kompetensi yang saat ini banyak diminati adalah Teknik Komputer dan Jaringan (TKJ) yang menerapkan disiplin ilmu dalam jaringan komputer, seputar permasalahan hardware komputer dan pengolahan informasi. Sebagai salah satu disiplin ilmu yang berasal dari bidang kompetensi teknologi informasi dan komunikasi, TKJ mempunyai peran penting dalam mengolah informasi yang dulunya secara konvensional menjadi berbasis elektronik. Selain hal itu adanya arus informasi yang tidak dapat dibendung melalui media informasi, 
khususnya internet merupakan bukti bahwa semakin pentingnya pengolahan informasi berbasis elektronik. Informasi merupakan kunci menuju kesuksesan, peribahasa tersebut terbukti bukan isapan jempol semata. Saat ini bila kita menguasai informasi maka kita dapat mengatur dan menginformasikan segala hal yang kita inginkan. Inilah yang perlu kita cermati untuk terus membimbing peserta didik kita untuk mampu menguasai bidang informasi dan komunikasi. Dengan tujuan agar tidak tertinggal dari bangsa lainnya untuk terus maju dan maju.

Hal inilah yang menjadikan kompetensi keahlian TKJ menjadi salah satu trend center dikalangan peserta didik SMP yang akan melanjutkan jenjang berikutnya. Secara financial kompetensi keahlian TKJ merupakan kompetensi yang memiliki market yang besar, mulai dari warnet (warung internet), toko komputer sampai industri elektronik papan atas membutuhkan karyawan dibidang tersebut. Bisa dibayangkan tanpa adanya orang yang berkompeten dalam bidang ini maka akan banyak laptop/ komputer yang akan dibuang secara masal karena kerusakan yang sebenarnya mampu ditangani oleh peserta didik SMK kompetensi keahlian TKJ. Pendekatan school-to-work transition yang dilakukan di sekolah-sekolah Amerika, yang memfokuskan pengkajiannya pada permasalahan peralihan dari dunia pendidikan ke dunia kerja, menjadi penting untuk dicermati. Pendekatan ini sekarang telah diadopsi secara luas di seluruh dunia dan akan semakin menempatkan industri sebagai tempat belajar yang sangat penting bagi sekolah kejuruan. Demikian juga dukungan dasar filosofi dan konsepnya telah tersedia. Pola penyelenggaraan pendidikan dan pelatihan kejuruan yang berdasarkan dasar fisosofi dan konsep ini telah banyak dikembangkan di banyak negara dan dalam jumlah yang sedikit dikembangkan di Indonesia (Billet, 2011).

Penyelenggaraan SMK yang berorientasi pada dunia kerja mengarahkan penyelenggara pendidikan untuk menyesuaikan proses belajar sedekat mungkin dengan realitas di lapangan. Dengan kata lain dapat diartikan bahwa untuk mendapatkan efesiensi dan efektivitas yang tinggi, pendidikan dan pelatihan pada pendidikan kejuruan harus dilatih dengan masalah, cara dan alat yang sama atau merupakan tiruan dari lingkungan di mana mereka akan bekerja nanti. Selain itu pendidikan kejuruan akan lebih efektif bila peserta didik dibiasakan untuk berfikir 
dan berperilaku yang sama dengan aktifitas tempatnya bekerja kemudian hari (Camp and Hilison, 1984).

Pendidikan formal dilaksanakan secara berjenjang dan berkesinambungan dimulai dari Pendidikan Dasar, Pendidikan Menengah, dan Pendidikan Tinggi. Sekolah Menengah Kejuruan (SMK) adalah salah satu pendidikan formal pada jenjang Pendidikan Menengah yang mempersiapkan peserta didik menjadi tenaga terampil tingkat menengah (middle skill) dan profesional di bidangnya masingmasing. Salah satu program pendidikan kejuruan adalah dengan Praktik Kerja Industri (prakerin).Prakerin merupakan sarana latihan yang tepat bagi peserta didik, karena peserta didik dituntut untuk melaksanakan pekerjaan yang sesuai dengan dunia kerja, prakerin adalah suatu bentuk pendidikan dan pelatihan yang dilaksanakan di industri atau dunia kerja secara terarah dengan tujuan untuk membekali peserta didik dengan sikap dan ketrampilan sesuai dengan cara belajar langsung di industri.

Namun dalam pelaksanannya sendiri prakerin justru tidak menunjukkan hasil yang maksimal dilihat dari kesiapan peserta didik prakerin di semester 3 yang menimbulkan pertanyaan, apakah peserta didik siap dengan rutinitas DU/DI? apakah kompetensi peserta didik sudah terukur? Hal inilah yang menjadi pertanyaan besar apakah memang benar-benar kesiapan belajar peserta didik mempunyai hubungan positif dengan hasil prakerin peserta didik. Selain hal tersebut lama waktu pelaksaan prakerin (lama pembelajaran) juga merupakan permasalahan yang perlu diteliti karena terdapat perbedaan waktu pelaksanaan prakerin di setiap sekolah, menurut observasi awal penelitian di Kota Batu prakerin dilaksanakan antara rentang waktu 2 bulan sampai 1 tahun. Sesuai dengan kebijaksanaan pihak sekolah, hal inilah yang memunculkan asumsi awal bahwa prakerin yang lebih lama rentan waktunya belum tentu lebih baik hasilnya dari prakerin yang rentan waktunya lebih sedikit, semisal 2 bulan prakerin dibandingkan dengan 1 tahun prakerin.

Kesesuain tempat prakerin juga menjadi salah satu fenomena saat ini, terlepas dari anggapan miring prakerin hanya merupakan formalitas kelulusan SMK. Kesesuain tempat prakerin dengan bidang keahlian peserta didik terkadang luput diperhatikan, padahal kesesuain tempat inilah yang menjadi dasar linieralitas keberhasilan pencapaian kompetensi keahlian dengan hasil prakerin peserta didik. 
Dengan memperhatikan kesesuain tempat prakerin dengan bidang keahlian peserta didik tidak akan ada lagi kasus peserta didik menganggur saat menjalani prakerin di tempat DU/DI (Koran Pendidikan, Halaman 14 Tahun 2008).

Selain hal tersebut perlu digarisbawahi pula pihak DU/DI juga perlu memperhatikan dan turut serta mendidik peserta didik di tempat DU/DI. Bukan hanya memberi pekerjaan, namun juga memberikan pengetahuan etos kerja yang baik dan ikut serta dalam mengatur iklim kerja yang nyaman. Partisipasi DU/DI inilah yang menjadi salah satu faktor yang mungkin mempengaruhi hasil prakerin peserta didik.

Menurut data statistik dari Direktorat Pembinaan Sekolah Kejuruan di Kota Batu terdapat 12 SMK yang berstatus negeri dan swasta yang terbagi dalam 2 sekolah negeri dan 10 lainnya merupakan sekolah swasta, sekolah yang memiliki kompetensi TIK hanya 2 sekolah, dari data tersebut dapat di tarik pemahaman awal jumlah SMK swasta di Kota Batu lebih banyak dari sekolah negeri, mengingat cakupan daerah di Kota Batu yang tidak terlalu luas. Selain hal tersebut DU/DI di Kota Batu yang bergerak pada Bidang Teknologi Informasi dan Komunikasi (TIK) juga sangat minim, sehingga perkembangan TIK di Kota Batu cukup lambat dibandingkan perkembangan bidang seni, kerajinan dan pariwisata yang berkembang pesat. Bila dibandingkan dengan Kota Malang yang memiliki sekitar 52 SMK negeri dan swasta yang 31 diantaranya memiliki bidang kompetensi TIK (Direktorat Pembinaan Sekolah Kejuruan) memang sangat jauh, mengingat DU/DI yang bergerak dibidang TIK lebih banyak di Kota Malang. Salah satu alasan penelitian di Kota Batu adalah keadaan SMK bidang kompetensi TIK yang minim dan perkembangan DU/DI bidang TIK yang terkalahkan oleh bidang pariwisata, padahal secara tidak langsung adanya perkembangan pariwisata harus dibarengi dengan ketersedian informasi yang ter-update, fleksibel dan terpercaya yang merupakan salah satu bidang cakupan TIK.

Selain hal tersebut kompetensi keahlian Teknik Komputer dan Jaringan (TKJ) di SMK Kota Batu merupakan salah satu kompetensi yang paling lama dibuka setelah kompetensi keahlian akutansi dan paling banyak peminatnya (Data Pokok SMK Jawa Timur) data rinci dapat dilihat pada Lampiran 13, sehingga dapat diambil 
kesimpulan awal kompetensi keahlian TKJ di Kota Batu sudah berdiri lama dan memiliki perangkat mengajar dan tenaga pengajar yang relevan.

\section{METODE}

Penelitian ini bertujuan untuk mengetahui hubungan serta sumbangan efektif variabel kesiapan belajar, lama pembelajaran, kesesuain tempat dan partisipasi DU/DI dengan hasil prakerin peserta didik kompetensi keahlian TKJ di SMK Kota Batu. Penelitian ini menggunakan pendekatan kuantitatif dengan rancangan penelitian korelasional. Hal ini sesuai dengan yang dikemukakan Sudjana dan Ibrahim (2007:77) "studi korelasi mempelajari hubungan dua variabel atau lebih, yakni sejauh mana variasi dalam satu variabel berhubungan dengan variasi dalam variabel lain".

Populasi dalam penelitian ini adalah peserta didik kelas XI Tahun Ajaran 2012/2013 di SMK Kota Batu yang memiliki kompetensi keahlian TKJ (Teknik Komputer dan Jaringan) dan sudah melaksanakan kegiatan praktek industri. Dari 12 SMK negeri dan swasta yang memiliki program keahlian TKJ yaitu SMK Islam Batu dan SMK Brawijaya Batu (Data Pokok PSMK, 2012). Pemilihan kompetensi keahlian TKJ dengan asumsi kompetensi keahlian yang paling banyak di Malang Raya (Kabupaten Malang dan Kota Batu). Sampel penelitian ditentukan dengan cara teknik Simple Random Sampling karena pengambilan sampel dilakukan tanpa memperhatikan strata yang ada dalam populasi itu (Sugiyono, 2009:62). Teknik Simple Random Sampling digunakan dengan tujuan memberikan kesempatan yang sama kepada semua anggota populasi untuk ditetapkan sebagai anggota sampel. Kemudian jumlah ukuran sampel ditentukan menggunakan bantuan SPSS Versi 18 dengan memilih menu Data-Select Cases - Random Samples of Cases yang menghasilkan 48 sampel. Instrumen yang digunakan tergolong dalam instrumen Non-Test, teknik Non-Test merupakan teknik penilaian untuk memperoleh gambaran terutama mengenai karakteristik, sikap, atau kepribadian peserta didik yang tidak dapat dinilai secara kuantitatif seperti dalam teknik tes (Sudjana dan Ibrahim, 2007:90). Analisis data dilakukan untuk menguji hipotesis penelitian. Adapun tahap untuk mencapai tujuan yang telah ditetapkan adalah dengan melakukan uji prasayarat 
analisis yang terdiri dari uji normalitas, linearitas, multikolinearitas dan heterosdastisitas. Setelah uji prasyarat analisis dilakukan maka dilakukan uji korelasi ganda dan uji regresi ganda

\section{HASIL DAN PEMBAHASAN}

Pada hasil uji prasyarat analisis diperoleh hasil bahwa penelitian ini telah memnuhi uji normalitas, uji multikinearitas dan uji heteroskesdastisitas. Langkah selanjutnya yaitu analisis korelasi gandan dan regresi ganda. Pada penelitian ini terdapat 5 hubungan yang signifikan, yaitu hubungan $\mathrm{X}_{1} \rightarrow \mathrm{Y}, \mathrm{X}_{2} \rightarrow \mathrm{Y}, \mathrm{X}_{3} \rightarrow \mathrm{Y}$, $\mathrm{X}_{4} \rightarrow \mathrm{Y}$ dan terakhir hubungan $\mathrm{X}_{1}, \mathrm{X}_{2}, \mathrm{X}_{3}, \mathrm{X}_{4} \rightarrow \mathrm{Y}$. Hasil penelitian dijelaskan dalam Tabel dan digambarkan dalam analisis korelasi tampak sebagai berikut.

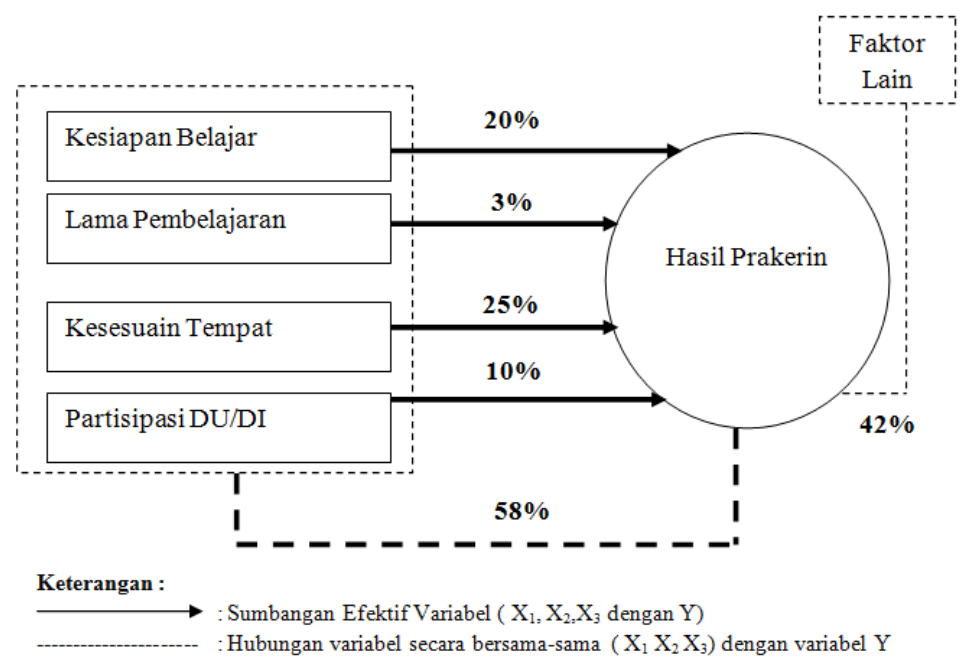

Gambar 1. Hubungan dan Sumbangan Antar Variabel

Tabel 1 Rangkuman Hasil Analisi Korelasi Ganda Antar Variabel Penelitian

\begin{tabular}{|c|c|c|c|c|}
\hline \multirow[t]{2}{*}{ Nama Variabel } & \multirow{2}{*}{$\begin{array}{l}\text { Koefisien } \\
\text { Korelasi }\end{array}$} & \multicolumn{2}{|c|}{ Probabilitas } & \multirow{2}{*}{$\begin{array}{c}\text { Interpretasi } \\
\mathrm{P}_{\text {hitung }}<\mathrm{Pstanda}\end{array}$} \\
\hline & & $P_{\text {hitung }}$ & $\mathrm{P}_{\text {standar }}$ & \\
\hline Kesiapan Belajar $\left(\mathrm{X}_{1}\right)$ & 0,500 & 0,000 & 0,05 & (+) \&Signifikan \\
\hline \multirow{2}{*}{$\begin{array}{l}\text { Lama Pembelajaran } \\
\left(\mathrm{X}_{2}\right)\end{array}$} & 0,321 & 0,013 & 0,05 & (+) \&Signifikan \\
\hline & 0,692 & 0,000 & 0,05 & (+) \&Signifikan \\
\hline $\begin{array}{l}\text { Kesesuain Tempat } \\
\left(\mathrm{X}_{3}\right)\end{array}$ & 0,712 & 0,000 & 0,05 & (+) \&Signifikan \\
\hline Partisipasi DU/DI $\left(\mathrm{X}_{4}\right)$ & - & 0,000 & 0,05 & (+) \&Signifikan \\
\hline $\begin{array}{l}\left(\mathrm{X}_{1}, \mathrm{X}_{2}, \mathrm{X}_{3}, \mathrm{X}_{4},\right) \text { Secara } \\
\text { Bersama-sama }\end{array}$ & & & & \\
\hline
\end{tabular}




\section{Hubungan Kesiapan Belajar dengan Hasil Prakerin Peserta Didik Kompetensi Keahlian TKJ di SMK Kota Batu.}

Pada Tabel 1 dapat dilihat, bahwa nilai koefisien korelasi ganda antara $\mathrm{X}_{1}$ dengan Y yaitu $\mathrm{r}_{\mathrm{x} 1 \mathrm{y}}$ sebesar 0,500 dengan probabilitas $\mathrm{p}$ hitung $<\mathrm{p}$ standar, yaitu $0,000<0,05$. Dengan demikian $\mathrm{H}_{0}$ ditolak dan terima $\mathrm{H}_{\mathrm{a}}$, artinya terdapat hubungan yang signifikan antara kesiapan belajar dengan hasil prakerin peserta didik kompetensi keahlian TKJ di SMK Kota Batu pada taraf signifikansi 5\%. Hubungan ini bersifat positif artinya adanya kesiapan belajar yang baik akan menghasilkan hasil prakerin yang baik, senada dengan hasil tersebut penelitian Rukmana (2011) mengenai "Hubungan Praktik Kerja Industri (Prakerin) Terhadap Kesiapan Peserta didik Bekerja Di Dunia Industri” juga menghasilkan hubungan yang kuat antara prakerin dengan kesiapan peserta didik bekerja di DU/DI. Hal ini membuktikan teori yang dikemukakan (Majid, 2005:24). "Competency based education is geared toward preparing individuals, to perform identified competency"

Pendidikan berbasis kompetensi yang identik dengan mempersiapkan kesiapan seseorang secara nyata sebelum melaksanakan suatu kegiatan yang bersifat skill dengan tujuan kenyaman individu ini merupakan suatu proses yang hampir sama mempersiapkan kesiapan belajar sedini mungkin untuk mengenal DU/DI. Kesiapan sangat penting untuk memulai suatu pekerjaan, karena dengan memiliki kesiapan, pekerjaan apapun akan dapat teratasi dan dikerjakan dengan lancar sehingga memperoleh suatu hasil yang baik pula. Kesiapan ini akan menjadi salah satu faktor yang penting dalam prakerin, mengingat dalam rancangan prakerin memiliki tujuan untuk pengembangan kemampuan melakukan tugas-tugas tertentu yang sesuai dengan standar performansi yang telah ditetapkan.

\section{Hubungan Lama pembelajaran Prakerin dengan Hasil Prakerin Peserta Didik Kompetensi Keahlian TKJ di SMK Kota Batu}

Pada Tabel 1 dapat dilihat, bahwa nilai koefisien korelasi ganda antara $\mathrm{X}_{3}$ dengan $\mathrm{Y}$ yaitu $\mathrm{r}_{\mathrm{x} 3}$ y sebesar 0,321 dengan probabilitas $\mathrm{p}$ hitung $<\mathrm{p}$ standar, yaitu $0,013<0,05$. Dengan demikian $\mathrm{H}_{0}$ ditolak dan terima $\mathrm{H}_{\mathrm{a}}$, artinya terdapat hubungan yang signifikan antara kesesuain tempat prakerin dengan hasil prakerin peserta didik kompetensi keahlian TKJ di SMK Kota Batu pada taraf signifikansi 
5\%. Hubungan ini bersifat positif dalam artian benar-benar memiliki pengaruh terhadap hasil prakerin, meskipun dibuktikan pada Bab VI Tabel 4.12 dijelaskan bahwa lama pembelajaran prakerin memberi sumbangan 3\% dari 58\% sumbangan setiap variabel dalam penelitian ini.

Hal ini tidak menjadi masalah karena bila lama pembelajaran prakerin di imbangi dengan kesesuain tempat prakerin hal ini akan menjadi berbanding terbalik, mengingat kesesuaian tempat prakerin memberikan sumbangan efektif yang paling banyak. Sebagai bahan rujukan sebenarnya lama pembelajaran prakerin memiliki dampak psikologis kepada peserta didik prakerin. Semakin lama berada di tempat prakerin akan mengakibatkan berubahnya attitude, dalam hal ini sikap yang berkaitan dengan pribadi individu. Sebagai contoh ketika berada di tempat prakerin peserta didik dibebaskan untuk berpakaian yang minim, mengecat rambut dan pulang malam. Sedikit banyak hal ini mempengaruhi secara psikologi pemahaman anak tentang DU/DI, hal inilah yang menjadi ketakutan tersendiri bagi guru pembimbing prakerin dan orang tua terhadap perubahan sikap peserta didik setelah melaksanakan prakerin, terutama apabila prakerin tersebut terlalu lama. Dari temuan penelitian tersebut perlu adanya penyesuain lama pembelajaran yang terorganisir yang diperkuat dengan penelitian lain yang membahas psikologi peserta didik bila dilihat dari ranah lama pembelajaran prakerin oleh pihak terkait, dalam hal ini adalah dinas pendidikan dan kebudayaan nasional. Sehingga diharapkan di masa mendatang akan muncul sistem prakerin yang bukan hanya sesuai dengan kemampuan peserta didik, namun juga sesuai dengan psikologi peserta didik.

\section{Hubungan Kesesuain Tempat Prakerin dengan Hasil Prakerin Peserta Didik Kompetensi Keahlian TKJ di SMK Kota Batu.}

Pada Tabel 1 dapat dilihat, bahwa nilai koefisien korelasi ganda antara $\mathrm{X}_{3}$ dengan Y yaitu $\mathrm{r}_{\mathrm{x} 3 \mathrm{y}}$ sebesar 0,692 dengan probabilitas $\mathrm{p}$ hitung $<\mathrm{p}$ standar, yaitu $0,000<0,05$. Dengan demikian $\mathrm{H}_{0}$ ditolak dan terima $\mathrm{H}_{\mathrm{a}}$, artinya terdapat hubungan yang signifikan antara partisipasi DU/DI dengan hasil prakerin peserta didik kompetensi keahlian TKJ di SMK Kota Batu pada taraf signifikansi 5\%.

Hubungan tersebut bersifat positif dalam artian hubungan kesesuain tempat prakerin memberikan dampak yang baik dan memberikan sumbangan yang paling banyak diantara variabel-variabel yang diteliti dalm penelitian ini. 
Hal ini dimungkinkan terjadi karena kesesuain tempat prakerin diartikan sebagai kesesuain bidang kompetensi keahlian dengan tempat magang peserta didik di industri, pada sub variabelnya sendiri dibagi menjadi dua, yakni kesesuain tempat dan kesesuain bidang, kesesuaian tempat lebih mengarah pada pelaksanana prakerin pada perusahaan yang memiliki brand name teknologi informasi, sedangkan kesesuain bidang lebih condong pada kesesuain bidang keahlian dengan pekerjaan yang dilakukan disaat prakerin. Secara konseptual hubungan kesesuain prakerin dengan hasil prakerin memang erat kaitannya, hal ini senada dengan penelitian Budi (2010), dengan judul "Hubungan Kesesuain Tempat Praktik Dan Motivasi Praktik dengan peran DU/DI" subyek dalam penelitian tersebut adalah peserta didik kelas XI program keahlian teknik mesin di kota tulungagung. Pada penelitian yang dilaksanakan Budi mengungkap korelasi yang tinggi sebesar 0,07\% dari standar deviasi sehingga dapat disimpulkan kesesuain tempat prakerin lebih menyumbang sebesar 35\% kontribusi terhadap peran DU/DI. Bila ditelaah lebih lanjut antara penelitian ini dengan penelitian Budi memiliki kesamaan menggunakan variabel kesesuain tempat prakerin yang berhubungan dengan prakerin dan kedua-duanya membuktikan adanya hubungan yang signifikan. Sehingga dapat disimpulkan kesesuain tempat prakerin memang secara nyata dan dibuktikan dengan hasil penelitian memiliki kontribusi yang signifikan terhadap hasil prakerin.

\section{Hubungan Partisipasi DU/DI dengan Hasil Prakerin Peserta didik Kompetensi Keahlian TKJ di SMK Kota Batu}

Berdasarkan Pada Tabel 1 dapat dilihat, bahwa nilai koefisien korelasi ganda antara $\mathrm{X}_{4}$ dengan $\mathrm{Y}$ yaitu ${ }_{\mathrm{rx}}$ y sebesar 0,712 dengan probabilitas $\mathrm{p}$ hitung $<\mathrm{p}$ standar, yaitu $0,000<0,05$. Dengan demikian $\mathrm{H}_{0}$ ditolak dan terima $\mathrm{H}_{\mathrm{a}}$, artinya ada hubungan yang signifikan antara partisipasi DU/DI dengan hasil prakerin peserta didik kompetensi keahlian TKJ di SMK Kota Batu pada taraf signifikansi 5\%. Bila dilihat nilai median pada data penelitian, partisipasi DU/DI termasuk dalam kategori tinggi pada point 4, sehingga dapat disimpulkan adanya keikutsertaan DU/DI memibimbing peserta didik akan menimbulkan hasil yang maksmial, memang secara teoritik seharusnya ketika DU/DI mau membantu dan membimbing secara nyata, kemampuan peserta didik yang berkaitan dengan kompetensi keahliannya akan meningkat secara drastis karena DU/DI memiliki 
peralatan yang canggih yang mengikuti perkembangan teknologi saat ini yang mungkin saja belum terdistribusi ke sekolah informasinya, yang otomatis berdampak pada pemahaman peserta didik yang mungkin saja lebih memahaminya dari pada guru disekolah. Inilah sebenarnya yang diharapkan sekolah kepada peserta didik yang melaksanakan prakerin selain mewujudkan jalinan kerjasama antara DU/DI dan sekolah.

Konsep seperti ini disebut situated learning dan work-based learning (belajar berbasis tempat kerja) yang mewujudkan adanya sinkronisasi dan update pengetahuan terkini yang ada pada DU/DI dengan perantara partisipasi DU/DI yang diwujudkan dengan keikutsertaan DU/DI membimbing dan membantu peserta didik prakerin dengan konsep tersebut.

Hubungan Kesiapan Belajar, Lama Pembelajaran, dan Kesesuain Tempat dengan Hasil Prakerin Peserta Didik Kompetensi Keahlian TKJ di SMK Kota Batu

Pada Tabel 1 dapat dilihat, nilai koefisien korelasi ganda antara $\mathrm{X}_{1}, \mathrm{X}_{2}, \mathrm{X}_{3}$, dan $\mathrm{X}_{4}$ dengan $\mathrm{Y}$ yaitu $\mathrm{R}$ sebesar 0,763 dan nilai $\mathrm{F}$ hitung sebesar 14,969 dengan probabilitas $\mathrm{p}_{\text {hitung }}<\mathrm{p}$ standar, yaitu $0,000<0,05$. Dengan demikian $\mathrm{H}_{0}$ diterima artinya terdapat hubungan yang signifikan antara kesiapan belajar, lama pembelajaran, kesesuain tempat dan partisipasi DU/DI secara bersama-sama dengan hasil prakerin peserta didik kompetensi keahlian TKJ di SMK Kota Batu pada taraf signifikansi $5 \%$.

\section{KESIMPULAN}

Berdasarkan hasil penelitian dan analisis data yang dilakukan, maka dapat diperoleh kesimpulan sebagai berikut: 1) kondisi kesiapan belajar peserta didik kompetensi keahlian TKJ di SMK Kota Batu berada pada kategori sedang, sehingga dapat disimpulkan peserta didik cukup siap untuk melaksanakan kegiatan prakerin yang dilaksanakan di DU/DI. Sedangkan lama pembelajaran masuk pada kategori rendah, fenomena ini dapat diartikan peserta didik memiliki pandangan bahwa lama pembelajaran tidak memberi dampak positif terhadap hasil prakerin selama tidak dibarengi dengan kesesuain tempat prakerin.

Kesesuaian tempat prakerin berada pada kategori kuat, hal ini dapat diartikan kesesuain tempat prakerin memiliki kontribusi yang besar terhadap kesuksesan 
prakerin yang dibuktikan dengan nilai hasil prakerin. Sedangkan partisipasi DU/DI berada pada kategori kuat, fenomena ini dapat diartikan bahwa peserta didik merasa partisipasi yang diberikan oleh DU/DI mampu memberikan dampak positif pada hasil prakerin; 2) ada hubungan yang signifikan antara kesiapan belajar dengan hasil prakerin peserta didik kompetensi keahlian TKJ di SMK Kota Batu. Hal ini berarti kesiapan belajar merupakan salah satu faktor yang menyumbang dampak positif terhadap hasil prakerin, sehingga apabila kesiapan belajar ditingkatkan maka hasil prakerin akan meningkat pula.

Dari analisis deskriptif angket dijelaskan bahwa peserta didik sebagian besar menyoroti ketidak nyamanan tempat DU/DI yang tidak memiliki fasilitas yang lengkap dan ruangan yang tidak terlalu luas. Sehingga perlu dipertimbangkan pemberian pemahaman kepada peserta didik tentang kondisi DU/DI yang sesungguhnya, khususnya pada toko komputer yang minim tempat, sebagai salah satu tujuan tempat prakerin peserta didik kompetensi keahlian TKJ; 3) ada hubungan yang signifikan antara lama pembelajaran dengan hasil prakerin peserta didik kompetensi keahlian TKJ di SMK Kota Batu. Dengan demikian, dapat disimpulkan bahwa lama pembelajaran memiliki dampak positif terhadap hasil prakerin meskipun didalam penelitian ini dibuktikan bahwa lama pembelajaran memberikan sumbangan efektif paling sedikit dari variabel yang lain. Dari sebaran angket terbuka juga terlihat peserta didik banyak menyoroti mengenai waktu kerja industri yang tidak mengenal waktu dari pagi sampai malam hari dan diluar kemampuan peserta didik. Hal ini menjadikan peserta didik tidak terlalu fokus dengan pekerjaan, karena faktor kelelahan. Sehingga perlu ditegaskan pada MOU prakerin dengan DU/DI untuk memberikan waktu prakerin yang sesuai dengan peserta didik; 4) ada hubungan yang signifikan antara kesesuain tempat prakerin dengan hasil prakerin peserta didik kompetensi keahlian TKJ di SMK Kota Batu. Fenomena ini dapat diartikan bahwa kesesuain tempat prakerin memberikan dampak yang sangat positif terhadap hasil prakerin, hal ini dibuktikan dengan sumbangan efektif yang paling besar diperoleh dari kesesuain tempat prakerin. Dari analisis deskriptif angket dijelaskan bahwa peserta didik sebagian besar merasa adanya penambahan kompetensi yang signifikan ditempat DU/DI. Hal ini dimungkinkan karena kesesuain tempat 
prakerin dengan bidang kompetensi keahlian terpenuhi, sehingga pembelajaran yang tidak didapatkan oleh peserta didik di sekolah, didapatkan di tempat DU/DI. 5) ada hubungan yang signifikan antara partisipasi DU/DI dengan hasil prakerin peserta didik kompetensi keahlian TKJ di SMK Kota Batu. Hal ini dapat diartikan partisipasi DU/DI memiliki hubungan positif terhadap hasil prakerin peserta didik. Hal ini sesuai dengan konsep yang dipaparkan peneliti pada Bab II, namun hal ini memang dimungkinkan, karena rata-rata peserta didik memberikan jawaban deskriptif pada angket terbuka dengan jawaban positif namun dengan beberapa alasan. Beberapa alasan tersebut kebanyakan peserta didik menyoroti masalah kurangnya pembimbingan pihak DU/DI selama peserta didik melaksanakan prakerin. Hal ini menimbulkan kesulitan peserta didik untuk mengeksplor kompetensi keahlian yang dimiliki; 6) terdapat hubungan yang signifikan secara bersama-sama antara kesiapan belajar, lama pembelajaran, kesesuaian tempat prakerin dan partisipasi DU/DI dengan hasil prakerin peserta didik kompetensi keahlian TKJ di SMK Kota Batu dengan sumbangan efektif variabel kesesuain tempat prakerin adalah yang paling besar dari variabel lainnya, kemudian disusul dengan sumbangan dari variabel kesiapan belajar, kemudian variabel partisipasi DU/DI dan yang paling kecil sumbangannya adalah lama pembelajaran. Fenomena ini dapat diartikan bahwa variabel kesiapan belajar, lama pembelajaran, kesesuain tempat prakerin dan partisipasi DU/DI tersebut erat kaitannya dengan hasil prakerin, apabila ketiga variabel tersebut dilaksanakan secara tepat maka akan terjadi pula kenaikan hasil prakerin peserta didik kompetensi keahlian TKJ.

\section{DAFTAR PUSTAKA}

Arikunto. 2007. Prosedur Penelitian Suatu Pendekatan Praktek. Jakarta : PT Rineka Bineka Cipta.

Billet, S. 2011. Vocational Education: Purpose, Traditions and Prospects. New York: Springer.

Brown, Balnaves.S.V 1998. Introduction to Learning Research Methods: An Investigative Approach. London: Sage Publications.

Camp \& Hillison. 1984. Prosser's Sixteen Theorm: Time For Reconsideration. Journal Of Vocational and Technical Education, Vol. 1, 13-21.

Cohen, M.J, dan N.T. Uphoff. 1977. Rural. Development Participation, Project 
Design And Implementation. New York.

Creswell, J.W. 2012. Educational Research: Planning, Conducting, and Evaluating Quantitative and Qualitative Researh, Fourth Edition. Boston: Pearson.

Dikmenjur. 1994. Profesionalitas Guru dalam Jabatan. Jakarta : Direktorat Pendidikan Mennegah dan Kejuruan.

Djamarah, B.S. 2002. Guru Dan Anak Didik Dalam Interaksi Edukatif. Jakarta. PT Rineka Cipta.

Kuncoro. 2009. Pendidikan dan Pembelajaran. Surakarta: Media Citra Lestari

Rouny. 2003. Statistik Praktis. Jakarta. Penerbitan PPM.

Richmond, G., \& Striley, J. 1996. Making Meaning in Classrooms: Social Processes in Small-Group Discourse and Scientific Knowledge Building. Journal of Research in Science Teaching, 839-858.

Sugiyono. 2005. Memahami Penelitian Kuantitatif: Dilengkapi Cntoh Proposal dan Laporan Penelitian. Bandung:Alfabeta.

Sugiyono. 2011. Metode Penelitian Kuantitatif, Kualitatif dan R\&D. Bandung: Alfabeta.

Slameto. 2003. Belajar dan Faktor-faktor yang Mempengaruhinya. Jakarta: Rineka Cipta.

Spencer.1993. Competence At Work Models For Superir Performance, Canada:John Wiley \& Son.

Stein, E. 1998. Using Secondary Data in Educational and Social Research. New York: McGraw-Hill.

Syaodih. 2007. Landasan psikologi Proses Pendidikan. Bandung. PT Remaja Rosdakarya.

Triton, N.K. 2005. Strategi dan Metode Pembelajaran. Surabaya : Graha Mandala Vygotsky, L.S. 1978. Mind in Society. Cambridge, MA: Harvard University Press. 